\title{
Diversity of floor vegetation in various levels in South Central Timor, East Nusa Tenggara, Indonesia
}

\begin{abstract}
The topographic conditions in South Central Timor which are prone to damage, require special attention in their utilization, such as through the application of the principles of soil and water conservation. This principle is not spared from the role of floor vegetation as grounding the blow of rainwater and surface flow so as to minimize the danger of erosion. This study aims to examine the diversity of floor vegetation in the karst ecosystem at various altitudes in South Central Timor. A total of 15 plots were placed along the elevation gradient starting from altitude of $307 \mathrm{~m}$ asl to $1782 \mathrm{~m}$ asl. Data was sampled using a $1 \mathrm{mx} 1 \mathrm{~m}$ subplot placed in plots of $20 \mathrm{~m} \times 20 \mathrm{~m}$. The results showed that the highest number of species was found in upland zone; as many as 61 species with the highest IV occupied by Cyperus rotundus L with a value of $40.2 \%$. In middle and and highland zones were Eleusine indica (L.) Gaertn and C. rotundus respectively, with $60.9 \%$ and $20.9 \%$ of IV. Diversity index at the research location was also classified as medium.
\end{abstract}

Keywords: diversity, floor vegetation, south central timo

\author{
Volume 2 Issue 5 - 2018
}

\author{
Fransisca Xaveriana Serafina Lio, Maria Paulin \\ Sari Dewi \\ Fakultas Keguruan dan Ilmu Pendidikan, Universitas Katolik \\ Widya Mandira, Indonesia
}

\begin{abstract}
Correspondence: Fransisca Xaveriana Serafina Lio, Fakultas Keguruan dan Ilmu Pendidikan, Universitas Katolik Widya Mandira, Jalan San Juan Penfui, Penfui Timur, Nusa Tenggara Timur,
\end{abstract} Indonesia, Email fransiscasarafina@gmail.com

Received: October 08, 2018 | Published: October 31, 2018

\section{Introduction}

Biodiversity is currently considered as one of the most important criteria for the sustainability of forest production. The main component of forest ecosystems, other than trees, is floor vegetation. ${ }^{1}$ Floor vegetation plays an important role in maintaining the structure and function of forest ecosystems, ${ }^{2}$ facilitating energy flows and nutrient cycles, and influencing canopy succession as a driver of forest ecosystems. ${ }^{3}$ Although floor vegetation contributes relatively little to total forest vegetation biomass, floor vegetation contributes the largest proportion of floristic diversity. ${ }^{4}$ In addition, the variety of floor vegetation can increase the complexity of the forest structure and provide habitat and food for other biotic groups; and increase the diversity of the floor vegetation itself. Understanding floor vegetation is also very important for forest regeneration, because floor vegetation can affect germination, survival and growth of tree seedlings by competing for light, water and nutrition or by allelopathic effects. ${ }^{5}$

Floor vegetation is used as an indicator of soil fertility and litter production in improving soil fertility. In addition to ecological functions, several types of understorey have been identified as plants that can be used as food, medicinal plants, and as alternative energy sources. But not infrequently also the understorey can act as a weed that inhibits tree regeneration, especially in cultivated monocultures. ${ }^{6}$

Based on its biophysical conditions, $72.27 \%$ of the area of South Central Timor Regency is in topographic conditions that are prone to damage, thus requiring special attention in its utilization, among others through the application of soil and water conservation principles. Attention is needed because the potential for surface erosion and landslides is high due to the opening of dry agricultural land or gardens, the use of fire in farming traditions, livestock cultivation; and the application of soil and water conservation principles are still very limited. ${ }^{7}$ The principle of soil and water conservation is not spared from the role of floor vegetation as grounding the blow of rainwater and surface flow so as to minimize the danger of erosion. More research has been carried out in the western part of West Timor, while biodiversity in the northern and southern parts of the island of Timor (Belu Regency, parts of South Central Timor and North Central Timor has not been explored much ${ }^{8}$ This study aims to examine the diversity of floor vegetation in the Karst Ecosystem at various altitudes in South Central Timor.

\section{Method}

A total of 15 plots were placed along the elevation gradient starting from a height of $300 \mathrm{~m}$ above sea level to $1800 \mathrm{~m}$ above sea level, divided into 3 zones namely the Middleland zone $(307-382 \mathrm{~m}$ asl), upland (784-1031m asl) and highland (1665-1782m asl). In the middleland zone, 4 plots were placed; in the upland zone as many as 7 plots and 4 in the highland zones. South Central Timor regency, which has a height of more than $500 \mathrm{~m}$ above sea level is approximately $51 \%$, while the rest is at an altitude of less than $500 \mathrm{~m}$ above sea level to the coastline area of $49 \%$ (BPS TTS, 2016) (Figure 1).

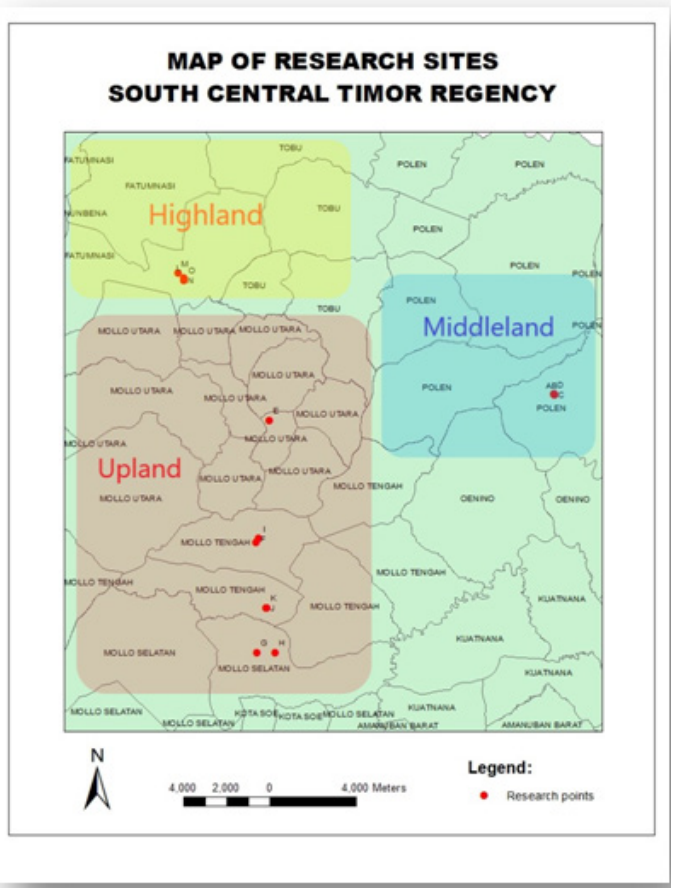

Figure I Research Location. 
Floor vegetation is vegetation with a height of less than $1 \mathrm{~m} .{ }^{9}$ Floor vegetation is classified into several life forms such as shrubs and tree seedlings, herbs, nails, and non-vascular plants. ${ }^{10}$

Floor vegetation parameters measured include:

a. Plant species

b. Number of individuals of each type

c. Density

d. Frequency of each species

To sample vegetation data, a $1 \mathrm{~m}$ x $1 \mathrm{~m}$ sub plot was placed in a plot measuring $20 \mathrm{~m} \times 20 \mathrm{~m} .{ }^{11}$ Floor vegetation is classified into several life forms such as shrubs and tree seedlings, herbs, nails, and other nonvascular plants. ${ }^{10}$

\section{Data analysis}

Vegetation - After the measurement data from the field is obtained, the data is tabulated and entered into MS Excel as a tool to calculate. The calculation for obtaining Important Value (IV) (Barbour et al, 1987) is as follows:

$$
\begin{aligned}
& \text { Density of species } A=\frac{\text { individual count of species A }}{\text { Area wide }} \\
& \text { Relative density of species } A=\frac{\text { a total count of species } A}{\text { density of whole species }} \times 100
\end{aligned}
$$

Frequency of species $A=\frac{\text { number of plots found species A }}{\text { number of whole plot }}$

Frequency relative of species $A=\frac{\text { frequency of species } A}{\text { frequency of whole species }} \times$
$100 \%$

Wide of basal area of species $\mathrm{A}=\pi(\text { stem radius of species } \mathrm{A})^{2}$

Wide of relative basal area of species $\mathrm{A}=$

$$
\frac{\text { wide of basal area of species A }}{\text { wide of basal area of whole species }} \times 100 \%
$$

Canopy wide of spesies $\mathrm{A}=\pi$ (lengths $\mathrm{x}$ width) canopy

Relative canopy wide of spesies $\mathrm{A}=$

$$
\frac{\text { canopy wide of species A }}{\text { canopy wide of whole species }} \times 100 \%
$$

IV of species A=Relative density of species A + Relative frequency of species A + Wide of basal area of species + Relative canopy wide of species $\mathrm{A}$

To predict species diversity for each study location, the Shannon diversity index was calculated ${ }^{12}$ using the formula:

$$
H^{\prime}=-\sum_{i=1}^{S} p i \ln p i
$$

Description:

$\mathrm{Pi}=$ individual number of each type $(\mathrm{i}=1,2,3, \ldots$.

$\mathrm{S}=$ number of types

$\mathrm{H}^{\prime}=$ index number

In $=$ logarithm naturally

\section{Results and discussion}

\section{Floor vegetation species}

A total of 27 species, 61 species and 30 species were found in the middle, upland and highland zones respectively. The types that have the most individuals in the middle zone are Eleusine indica (L.) Gaertn with a density of 2267 individuals/0.16ha and Important Value (IV) of $60.93 \%$. Cyperus rotundus L is has the most individuals in the upland zone with a density of 2889 individuals $/ 0.28$ ha and IV of $40.02 \%$, while in the highland zone Cyperus rotundus L. is also occupied with a density of 2253 individuals / 0.16 ha and IV of $29.69 \%$. An et al. ${ }^{13}$ revealed that E. indica is a herb that has a high level of fecundity and a wide tolerance to habitats that have various environmental factors. Types that have high IV indicate that the species is more adaptive and more able to adjust to environmental conditions than other types. The type that has the highest IV means that the species is able to utilize available resources better than other types. This is explained by Soerianegara \& Indrawan ${ }^{14}$ that plants have a very real correlation with their growth. Vegetation with high IV has an important role and can adapt to the environment, using energy sources in the community. ${ }^{15}$ The most important value owned by different species in the three sandalwood forests, indicates that these species have a great opportunity to spur growth and maintain the sustainability of the species (It meant floor vegetation). ${ }^{16}$ Based on the results of the analysis it was found that as many as 27 species belonging to 17 families were found in the middle land zone, with the family having the most number of individuals being poaceae (Table 1). The Poaceae has a light breeding tool, is easily dispersed and also has simple life requirements in various habitats. Poaceae has microscopic sized seeds that are easily carried by the wind; it has a high adaptability; distribution is very broad, and Poaceae family members are able to grow both on dry and inundated land. The properties possessed by the Poaceae family cause the members of the Poaceae family to be distributed widely in various habitats. ${ }^{17}$

Based on the results of the analysis, it is known that the species that dominate the research locations are also different (Table 2). This difference is due to each species dominating different regions. In addition, environmental conditions lead to competition between one species and another. Competition will increase the fighting power to sustain life, so that strong species will win and suppress other species. The losing species become less adaptive and cause low reproductive rates and are found in small numbers. ${ }^{18}$ Each type of plant has a minimum, maximum and optimum condition for the existing environmental factors. The species that dominates has e a wider range of tolerance. So that a wide range of tolerance for environmental factors enables this species to have a wide distribution. ${ }^{19,20}$

A total of 61 species belonging to 33 families were found in the upland zone, where families with the highest number of individuals were cyperaceae (Table 3 ). The cyperaceae family has an extraordinary diversity, with species found in almost all habitats except deserts and aquatic ecosystems. The majority of cyperaceae are plants that live in moist to wet habitats, such as ponds, grasslands, swamps and savannas. This species likes moist areas such as trenches and canal. Many cyperaceae species are also found in various types of forests, both temperate and tropical. ${ }^{21}$

The highland zone is included in the Mount Mutis Nature Reserve. Mount Mutis forest has a distinctive ecology. The Mount Mutis forest has a homogeneous vegetation composition, namely ampupu (Eucalyptus urophylla). This type of ecosystem does not exist in other regions. In addition, the Mount Mutis forest is located in a transition 
zone between Asia and Australia so that in the forest of Mount Mutis there are flora and fauna from both Asia and Australia. ${ }^{22}$ A total of 30 species belonging to 19 families were found in the highland zone (Table 4). The family that has the highest number of individuals is cyperaceae. In the highland zone several types of orchids, fungi, moss and lichens are also found. Types of fungi found include Pleurotus ostreatus, Ganoderma applanatum and Pleurotus cystidiosus. Types of moss found include Pellia endiviifolia, Anthoceros punctatus, and Polytrichum abbreviatum. Usnea sp. and Parmalia sp. also found in the highland zone. The orchid species found, live commensally with ampupu plants, as well as species of moss and lichens.

Table I Floor Vegetation in the Middle land Zone

\begin{tabular}{|c|c|c|c|c|c|}
\hline No & Local name & Species name & Family & $\begin{array}{l}\text { De ens i t y } \\
\text { (Ind./Ha) }\end{array}$ & IV (\%) \\
\hline I & Huk you & Eleusine indica (L.) Gaertn & Poaceae & 2267 & 60.9 \\
\hline 2 & Species A & Portulaca oleracea L. & Portulacaceae & 513 & 16.7 \\
\hline 3 & Huk Pisu & Axonopus compressus (Sw.) P. Beauv. & Poaceae & 355 & 10 \\
\hline 4 & Teak & Tectona grandis L.f. & Lamiaceae & 169 & 9.8 \\
\hline 5 & Purple flower & Stachytarpheta acuminata DC. ex Schauer & Verbenaceae & 159 & 8.1 \\
\hline 6 & Tapak Liman & Elephantopus scaber L. & Compositae & 131 & 8.9 \\
\hline 7 & Suf Muti & Chromolaena odorata (L.) R.M. King \& H.Rob. & Compositae & 95 & 8 \\
\hline 8 & Leaf paste clothes & Toxicodendron radicans (L.) Kuntze & Anacardiaceae & 76 & 6.1 \\
\hline 9 & Caliandra & Calliandra biflora Tharp & Leguminosae & 57 & 5.6 \\
\hline 10 & Acacia & Acacia mangium Wild. & Leguminosae & 52 & 8.4 \\
\hline 11 & Kabesak & Acacia leucophloea (Roxb.) Willd & Leguminosae & 49 & 6.9 \\
\hline 12 & Eucalyptus & Melaleuca leucadendra (L.) L. & Myrtaceae & 31 & 6.4 \\
\hline 13 & Temulawak & Curcuma aeruginosa Roxb. & Zingiberaceae & 25 & 2 \\
\hline 14 & Timu & Timonius sereceus (Desf) K. Schum & Rubiaceae & 24 & 3.4 \\
\hline 15 & Kusambi & Schleichera oleosa (Lour.) Merr. & Sapindaceae & 19 & 6.1 \\
\hline 16 & Mahogany & Swietenia macrophylla King & Meliaceae & 13 & 3.1 \\
\hline 18 & Kebo excerpts & Euphorbia hirta L. & Euphorbiaceae & 12 & 4.5 \\
\hline 17 & Masi & Bauhinia purpurea $\mathrm{L}$ & Leguminosae & 12 & 4.5 \\
\hline 20 & Guava & Psidium guajava $\mathrm{L}$ & Myrtaceae & 10 & 3.1 \\
\hline 19 & Sandalwood & Santalum album $\mathrm{L}$. & Santalaceae & 10 & 3.1 \\
\hline 21 & Biduri & Calotropis gigantea (L.) W.T.Aiton & Apocynaceae & 6 & 1.5 \\
\hline 22 & White flower & Hippobroma longiflora (L.) G.Don & Campanulaceae & 6 & 1.5 \\
\hline 23 & Petes & Leucaena leucocephala (Lam.) de Wit & Leguminosae & 5 & 2.9 \\
\hline 24 & White teak & Gmelina arborea Roxb. & Lamiaceae & 4 & 4.3 \\
\hline 25 & Mint leaves & Plectranthus amboinicus (Lour.) Spreng & Lamiaceae & 3 & 1.5 \\
\hline 26 & Mimosa & Mimosa pudica L. & Fabaceae & 2 & 1.4 \\
\hline 27 & Papih & Syzygium aromaticum (L.) Merr. L. M. Perry & Myrtaceae & I & 1.4 \\
\hline
\end{tabular}

Table 2 Dominant Species in Research Sites

\begin{tabular}{llll}
\hline Species & Zone & Upland & Highland \\
\cline { 2 - 4 } Middleland & Cyperus rotundus L & Cyperus rotundus L. & Centella asiatica (L.) Urb. \\
\cline { 2 - 4 } & Eleusine indica (L.) Gaertn & Plectranthus amboinicus (Lour.) Spreng & Elephantopus scaber L. \\
& Axonopus compressus (Sw.) P.Beauv. & Axonopus compressus (Sw.) P.Beauv. &
\end{tabular}

Solikin $^{23}$ revealed that the Mount Mutis Nature Reserve is dominated by ampupu plants, especially in savanna areas. Species of orchids found in Mount Mutis Nature Reserve include Bulbophyllum ovalifolium, Bulbophyllum odoratum, Ceratostylis radiate, Dendrobium kuhlii, Eria retusa, Eria rhynchostyloides and Pholidota rubra. In the highland zone grazing wild animals such as cattle and horses were also found. Livestock grazing in the Gunung Mutis forest has been long-standing and is the culture of the local community. This makes the grazing of livestock in the Mount Mutis forest difficult to prevent by the government. Pasture has an impact on tree regeneration so that the forest area used for grazing cannot change into forest again. This happened to the pasture fields in the Mutis forest area. 
Conversely, forests that have dense vegetation cannot produce animal the condition of forests which have low canopy density because they feed so they cannot be used for livestock grazing. Local people prefer can be used for grazing and feeding their livestock. ${ }^{22}$

Table 3 Floor vegetation in Upland Zone

\begin{tabular}{|c|c|c|c|c|c|}
\hline No & Local name & Species name & Family & Density (Ind./0.28 ha) & IV (\%) \\
\hline I & Cyperus & Cyperus rotundus $\mathrm{L}$ & Cyperaceae & 2889 & 40 \\
\hline 2 & Mint leaves & Plectranthus amboinicus (Lour.) Spreng & Lamiaceae & 685 & 8.9 \\
\hline 3 & Huk Pisu & Axonopus compressus (Sw.) P.Beauv. & Poaceae & 613 & 8.9 \\
\hline 4 & Purple flower & Stachytarpheta acuminata DC. ex Schauer & Verbenaceae & 559 & 12.4 \\
\hline 5 & Crocodile nest grass & Lophatherum gracile Brongn. & Poaceae & 475 & 7.2 \\
\hline 6 & Reeds & Imperata cylindrica (L.) Raeusch & Poaceae & 432 & 5.9 \\
\hline 7 & Leaves & Plantago major L. & Plantaginaceae & 397 & 6.3 \\
\hline 8 & Papo'e & Arachis pintoi Krapov. \&W.C Greg & Leguminosae & 337 & 8.1 \\
\hline 9 & Elephant grass & Poa trivialis L. & Poaceae & 303 & 4.4 \\
\hline 10 & Species A & Portulaca oleracea L. & Portulacaceae & 226 & 4.3 \\
\hline II & $\begin{array}{l}\text { Leaf shape of the } \\
\text { heart }\end{array}$ & Mikania micrantha Kunth & Compositae & 158 & 3.5 \\
\hline 12 & Sapotilii & Ficus natalensis Hochst. & Moraceae & 157 & 3.5 \\
\hline 13 & Kebo excerpts & Euphorbia hirta L. & Euphorbiaceae & 154 & 4.3 \\
\hline 14 & Suf Muti & Chromolaena odorata (L.) R.M.King \& H.Rob. & Compositae & 153 & 6 \\
\hline 15 & Fua Koti & Phyllanthus urinaria $\mathrm{L}$. & Phyllanthaceae & 136 & 3.2 \\
\hline 16 & Kiun'ut & Cosmos caudatus Kunth. & Compositae & 116 & 3 \\
\hline 17 & Petes & Leucaena leucocephala (Lam.) de Wit & Leguminosae & 92 & 5.2 \\
\hline 18 & Liman footprint & Elephantopus scaber L. & Compositae & 88 & 1.8 \\
\hline 19 & Maleku & Oxalis corniculata L. & Oxalidaceae & 72 & 1.6 \\
\hline 20 & White flower & Hippobroma longiflora (L.) G.Don & Campanulaceae & 62 & 3.2 \\
\hline 21 & Guava & Psidium guajava $\mathrm{L}$ & Myrtaceae & 48 & 4.7 \\
\hline 22 & Sandalwood & Santalum album L & Santalaceae & 31 & 1.2 \\
\hline 23 & Species C & Emilia sonchifolia (L.) DC. ex DC. & Compositae & 26 & 1.9 \\
\hline 24 & King rass & Pennisetum purpureum Schumach. & Poaceae & 26 & I.I \\
\hline 25 & Bakoma'a & Hyptis capitata Jacq. & Lamiaceae & 23 & 1.9 \\
\hline 26 & Mahogany & Swietenia macrophylla King & Meliaceae & 20 & 1.9 \\
\hline 27 & Pangkase & Lantana camara L. & Verbenaceae & 20 & 2.7 \\
\hline 28 & White teak & Gmelina arborea Roxb. & Lamiaceae & 19 & 2.7 \\
\hline 29 & Caliandra & Calliandra biflora Tharp & Leguminosae & 18 & 2.7 \\
\hline 30 & Acacia & Acacia mangium Wild. & Leguminosae & 17 & 4.4 \\
\hline 31 & Pulai & Alstonia scholaris (L.) R. Br. & Apocynaceae & 15 & I \\
\hline 32 & Bandotan & Ageratum conyzoides (L.) L. & Compositae & 14 & 1.8 \\
\hline 33 & Kuk Nefo & Tridax procumbens (L.) L. & Compositae & 14 & 1.8 \\
\hline 34 & Mimosa & Mimosa pudica L. & Fabaceae & 11 & 0.9 \\
\hline 35 & Euporbia & Euphorbia heterophylla L. & Euphorbiaceae & 6 & 0.9 \\
\hline 36 & Venus & Senna siamea (Lam.) H.S.Irwin \& Barneby & Leguminosae & 6 & 1.7 \\
\hline 37 & Put'puta & Polygala paniculata L. & Polygalaceae & 5 & 0.8 \\
\hline 38 & Paria forest & Tithonia diversifolia (Hemsl.) A.Gray & Compositae & 4 & 0.8 \\
\hline 39 & Nombesa & Talinum fruticosum (L.) Juss & Talinaceae & 4 & 0.8 \\
\hline 40 & $\begin{array}{l}\text { White } \\
\text { trumpet }\end{array}$ & Hymenocallis acutifolia (Herb. ex Sims) Sweet & Amaryllidaceae & 3 & 1.7 \\
\hline $4 I$ & Papa'i & Sida cordifolia L. & Malvaceae & 3 & 0.8 \\
\hline
\end{tabular}




\begin{tabular}{|c|c|c|}
\hline 42 & Gotu kola & Centella asiatica (L.) Urb. \\
\hline 43 & Biduri & Calotropis gigantea (L.) Dryand \\
\hline 44 & Teak & Tectona grandis L.f. \\
\hline 45 & Kusambi & Schleichera oleosa (Lour.) Merr. \\
\hline 46 & Red ginger & Zingiber officinale Roscoe \\
\hline 47 & Baunoet & Spigelia anthelmia L. \\
\hline 48 & Nabasbot & Hibiscus trionum L. \\
\hline 49 & Bonsai & Streblus asper Lour \\
\hline 50 & Yellow flowers & Tribulus terrestris L. \\
\hline 51 & Taro & Colocasia esculenta (L.) Schott \\
\hline 52 & Sweet potato leaves & Manihot esculenta Crantz \\
\hline 53 & Kate is gold & Euphorbia heterophylla L. \\
\hline 54 & Gamal & Gliricidia sepium (Jacq.) Kunth ex Walp. \\
\hline 55 & Masi & Bauhinia purpurea $\mathrm{L}$ \\
\hline 56 & Species E & Sida rhombifolia L. \\
\hline 57 & Nails of deer horns & Platycerium bifurcatum (Cav.) C. Chr \\
\hline 58 & Pearl grass & Oldenlandia corymbosa L. \\
\hline 59 & Stir & Brucea javanica (L.) Merr \\
\hline 60 & eggplant & Solanum melongena $\mathrm{L}$. \\
\hline 61 & Turmeric & Curcuma longa L. \\
\hline
\end{tabular}

Table 4 Floor vegetation in the Highland Zone

\begin{tabular}{|c|c|c|c|c|c|}
\hline No & Local name & Species name & Family & Density & IV (\%) \\
\hline I & Cyperus & Cyperus rotundus L. & Cyperaceae & 2253 & 29.6 \\
\hline 2 & Gotu kola & Centella asiatica (L.) Urb. & Apiaceae & 1454 & 27.8 \\
\hline 3 & Liman footprint & Elephantopus scaber L. & Compositae & 911 & 18.4 \\
\hline 4 & Huk Pisu & Axonopus compressus (Sw.) P.Beauv. & Poaceae & 649 & 8.6 \\
\hline 5 & Crocodile nest grass & Lophatherum gracile Brongn. & Poaceae & 395 & 7.4 \\
\hline 6 & Elephant grass & Poa trivialis L. & Poaceae & 276 & 5.7 \\
\hline 7 & Kangkung Hutan & Ipomoea pes-caprae (L.) R. Br. & Convolvulaceae & 218 & 3.8 \\
\hline 8 & Leaf god & Gynura divaricata (L.) DC & Compositae & 215 & 1.9 \\
\hline 9 & Kebo excerpts & Euphorbia hirta L. & Euphorbiaceae & 183 & 8.3 \\
\hline 10 & Bunga mayana & Coleus aromaticus Benth. & Lamiaceae & 106 & 2.5 \\
\hline II & Reeds & Imperata cylindrica (L.) Raeusch & Poaceae & 79 & 4.4 \\
\hline 12 & Leaves & Plantago major L. & Plantaginaceae & 75 & 4.9 \\
\hline 13 & Papoe & Arachis pintoi Krapov. \&W.C Greg & Leguminosae & 64 & 2.8 \\
\hline 14 & Bandotan & Ageratum conyzoides (L.) L. & Compositae & 54 & 1.9 \\
\hline 15 & White flower & Hippobroma longiflora (L.) G.Don & Campanulaceae & 46 & 4 \\
\hline 16 & Ampupu & Eucalyptus urophylla S.T.Blake & Myrtaceae & 43 & 4.5 \\
\hline 17 & Cocor bebek & Bryophyllum pinnatum (Lam.) Oken & Crassulaceae & 39 & 18 \\
\hline 18 & Taro & Colocasia esculenta (L.) Schott & Araceae & 32 & 2.3 \\
\hline 19 & Kiun'ut & Cosmos caudatus Kunth. & Compositae & 30 & 2.3 \\
\hline 20 & Forest nuts & Senna occidentalis (L.) Link & Leguminosae & 27 & 6.8 \\
\hline 21 & The jungle forest & Spondias pinnata (L.F.) Kurz & Anacardiaceae & 16 & 2.1 \\
\hline 22 & Purple flower & Stachytarpheta acuminata DC. ex Schauer & Verbenaceae & 16 & 1.9 \\
\hline
\end{tabular}


Table Continued.....

\begin{tabular}{lll}
23 & White umbrella mushroom & Pleurotus ostreatus (Jacq.) P. Kumm. \\
24 & Betel stem forest & Peperomia luisana Trel. \& Standl. \\
25 & Wood mushrooms & Ganoderma applanatum (Pers.) Pat. \\
26 & Cat leaves & Plectranthus amboinicus (Lour.) Spreng \\
27 & Eucalyptus & Melaleuca leucadendra (L.) L. \\
28 & Chocolate umbrella mushrooms & Pleurotus cystidiosus O.K.Mill. \\
29 & Forest cherry & Syzygium cumini (L.) Skeels \\
30 & Pomegranate & Punica granatum L. \\
\hline
\end{tabular}

$\begin{array}{lll}\text { Pleurotaceae } & 6 & 6.1 \\ \text { Piperaceae } & 4 & 3.3 \\ \text { Ganodermataceae } & 2 & 1.9 \\ \text { Lamiaceae } & 2 & 1.9 \\ \text { Myrtaceae } & 2 & 2.3 \\ \text { Pleurotaceae } & 2 & 3.9 \\ \text { Myrtaceae } & 1 & 2.4 \\ \text { Lythraceae } & 1 & 6.2\end{array}$

The grazing of wild animals can also change the structure and composition of the forest constituents. Grass eating animals are the main key in the dynamics of vegetation in the ecosystem in general. However, with its position as a key driver, this affects the structure and composition of vegetation because the explosion of grazing animals can affect the process of vegetation regeneration, as well as change the structure and composition of vegetation. ${ }^{24-26}$ Increasing herbivory density results in decreased growth and the amount of seedling and sapling changing the woody-plant composition and native flora in an ecosystem, ${ }^{24,25,27}$ as well as potentially increasing the growth of other vegetation which is not used as food. ${ }^{26}$ The effects of high herbivory densities over a long period of time need special attention, especially in terms of conservation. ${ }^{26}$ The grazing of livestock in the wild can affect seed density, species richness and composition of bank seeds, and affect the amount of seeds produced through the reproduction process. ${ }^{28}$ Pol et al. ${ }^{29}$ revealed that grazing intensity can reduce productivity of productive plant parts so that the photesynthesis process decreases and the flowering process becomes inhibited, and thus causing a decrease in the amount of seed produced so that the availability of the seed bank in the soil is reduced.

\section{Diversity index}

A community is said to have high species diversity when it exists of many species. Conversely, a community is said to have low species diversity when it exists by a small number of species and if there are only a few dominant species. ${ }^{30}$ Based on the results of the analysis, it was found that the diversity index in all study locations was classified as medium (Table 5).

Table 5 Diversity Index Value

\begin{tabular}{ll}
\hline Zone & Diversity index \\
\hline Middleland & 1.19 \\
Upland & 1.51 \\
Highland & 1.29 \\
\hline
\end{tabular}

The diversity index classified as high when the value is more than 3, and classified as low wehen the values is less than 1 . The diversity of species classified as moderate is caused by environmental conditions that are less supportive for the growth and breeding of a plant species. The research area belongs to the karst region which has a nutrient-poor soil layer so that the species that grow in this karst area are only plant species that are able to adapt ${ }^{31}$ and have a high tolerance for drought. ${ }^{32-34}$

\section{Conclusion}

Based on the results of the analysis it can be concluded that the floor vegetation in the study location has a moderate level of diversity, with the highest number of species found in the upland zone. Dominant species are also different due to differences in location. The grazing

of wild animals in the highland zone can reduce the diversity of floor vegetation so that the interference of the government is needed by offering alternatives to the community. ${ }^{35}$

\section{Acknowledgments}

A thank you research team conveyed to the Directorate of Research and Community Service - Directorate General of Research and Development Strengthening - Ministry of Research. Technology, and Republic of Indonesia Higher Education that has funded this research. Also presented to the Research and Community Service Institute, Widya Mandira Catholic University which has helped the research team to provide research letters and facilitate the distribution of research funds.

\section{Conflict of Interest}

The author declares that there is no conflict of interest.

\section{References}

1. Burinaek V, Novotny R, Hellebrandova K, et al. Ground Vegetation as an Important in the Biodiversity of Forest Ecosystem and Its Evaluation in regard to Nitrogen Deposition. Journal of Forest Science. 2013;59(6):238-252.

2. Augusto 1, Dupouey J, Ranger J. Effects of tree species on understory vegetation and environmental conditions in temperate forests. Annals of Forest Science. 2003;60(8):823-831.

3. Hart SA, Chen HYH. Fire,logging,and overstory affect understory abundance, diversity, and composition in boreal forest. Ecological Monographs. 2008;78(1):123-140.

4. Gilliam FS. The ecological significance of the herbaceous layer in temperate forest ecosystems. BioScience. 2007;57(10):845-858.

5. Huo H, Feng Q, Su YH. The Influences of Canopy Species and Topographic Variables on Understory Species Diversity and Composition in Coniferous Forests. The Sciencetific Journal. 2014;2014:1-8.

6. Hilwan I, Idealisa M. Keanekaragaman Jenis Tumbuhan Bawah di Gunung Papandayan Bagian Timur, Garut, Jawa Barat. Jurnal Silvikultur Tropika. 2015;6(2):119-125.

7. Djurumana GND. Ekologi dan Pemanfaatan Nitas (Sterculia foetida L.) di Kabupaten Timor Tengah Selatan, Nusa Tenggara Timur (Ecology and Utilization of Nitas (Sterculia foetida L.) on Timor Tengah Selatan Regency, East Nusa Tenggara). Jurnal Penelitian Hutan dan Konservasi. 2011;8(1):35-44.

8. Lesmana D, Trainor C, Gatur A. Arti Penting Hutan di Daratan Timor Bagian Barat. BirdLife International-Indonesia Programme. Bogor, Indonesia; 2000

9. Relva MA, Westerholm CL, Kitszberger T. Effects of Introduced Ungulates on Forest Understory Communities in Northern Patagonia are Modified by Timing and Severity of Stand Mortality. Journal Plant Ecology 2009;201(1):11-22. 
10. Chen HYH, Légaré S, Bergeron Yves. Variation of the understory composition and diversity along a gradient of productivity in Populus tremuloides stands of northern British Columbia, Canada. Canadian Journal of Botany. 2004;82(9):1314-1323.

11. Djohan TS. Petunjuk Praktikum Ekologi Lanjut Biologi. Universitas Gadjah Mada, Fakultas Biologi, Laboratorium Ekologi dan Konservasi. Yogyakarta; 2014.

12. Odum EP. Dasar-Dasar Ekologi. Edisi Ketiga. Diterjemahkan oleh T. Samingan, Yogyakarta: Universitas Gadjah Mada; 1993.

13. An JX, Shen X, Ma Q, et al. Transcriptome Profiling to Discover Putative Genes Associated with Paraquat Resistance in Goosegrass (Eleusineindica L.). PLOS One. 2014;9:1-14.

14. Soerianegara I dan A. Indrawan. Ekologi Hutan Indonesia. Bogor: Laboratorium Ekologi Hutan. Fakultas Kehutanan. Institut Pertanian Bogor; 1998.

15. Fatimatuzzahra R, Sancayaningsih P, Saputra dan A. Analisis Vegetasi Lantai Sebagai Penahan Limpasan Air di Sekitar Mata Air. Seminar Nasional XI Pendidikan Biologi FKIP UNS. Universitas Negeri Surakarta; 2014:AA617-621.

16. Mawazin, Subiakto A. Keanekaragaman dan Komposisi Jenis Permudaan Alam Hutan Rawa Gambut Bekas Tebangan di Riau (Species Diversity and Compositionof Logged Over Peat Swamp Forest in Riau). Forest Rehabilitation. 2013;1:59-73.

17. Rukmana R, dan Saputra US. Gulma dan Teknik Pengendalian. Jakarta: Kanisius; 1999.

18. Syamsuri IWR. Lingkungan Hidup Kita. Malang: PKPKLH IKIP Malang; 1997.

19. Barbour MG, Burk JH, Pitts WD. Terresterial Plant Ecology. 2nd ed. The Banjamin/Cummings Publishing Company, Inc; 1987.

20. Syafei ES. Pengantar Ekologi Tumbuhan. Bandung: Institut Teknologi Bandung; 1990.

21. Barret RL. Ecological Importance of Sedges: a survey of the Australasian Cyperaceae genus Lepidosperma. Annals of Botany 2013;111(4):499-529.

22. Kurniadi R, Purnomo H, Wijayanto N, et al. Model Pengelolaan Ternak di Sekitar Hutan Gunung Mutis dan Dampaknya terhadap Kelestarian Hutan. Jurnal Ilmu Kehutanan. 2017;11(2):156-172.

23. Solikin. The Exploration of Plant Spesies in Nature Reserve of Mount
East Nusa Tenggara Province. Journal of Biological Researches. 2015;21:51-55.

24. Koda R, Fujita N. Is Deer Herbivory Directly Proportional to Deer Population Density? Comparison of Deer Feeding Frequencies among Six Forests with Different Deer Density. Forest Ecology and Management. 2011;262(3):432-439.

25. Randall JA, Walters MB. Deer Density Effects on Vegetation in Aspen Forest Understories Over Site Productivity and Stand Age Gradients. Forest Ecology and Management 2011;261:408-415.

26. White MA. Long Term-Effects of Deer Browsing: Composition, Structure and Productivity in a Northeastern Minnesota Old-Growth Forest. Forest Ecology and Management. 2012;269:222-228.

27. Koh S, Bazely DR, Tanentzap AJ, et al. Trillium Grandiflorum Height is an Indicator of White-Tailed Deer Density at Local and Regional Scales. Forest Ecology and Management. 2010;259(8):1472-1479.

28. Loydi A, Zalba SM, Diestel RA. Viable Seed Banks Under Grazing and Exclosure Conditions in Montane Mesic Grasslands of Argentina. Acta Oecologica. 2012;43:8-15.

29. Pol RG, Sagario MC, Marone L. Grazing Impact on Desert Plants and Soil Seed Banks: Implications for Seed-Eating Animals. Acta Oecologica. 2014;55:58-65.

30. Indriyanto. Ekologi Hutan. PT Bumi Aksara. Jakarta; 2006.

31. Marwiyati. Ekologi Vegetasi dan Etnobotani Kawasan Karst Gunung Cibodas, Ciampea, Bogor. Departemen Biologi, Fakultas Matematika danIlmu Pengetahuan Alam. Institut Pertanian Bogor; 2012.

32. Heilman JL, Mclnnes KJ, Kjelgaard JF, et al. Energy Balance and Water Use in Subtropical Karst Woodland on the Edwards Plateau, Texas. Journal of Hidrology. 2009;373(3-4):426-435.

33. Lu X, Toda H, Ding F, et al. Effect of Vegetation Types on Chemical and Biological Properties of Soils of Karst Ecosystems. European Journal of Soil Biology. 2014;61:49-57.

34. Liu CC, Liu YG, Fan DY, et al. Plant Drought Tolerance Assessment for Re-vegetation in Heterogeneous Karst Landscape of Southwestern China. Flora. 2012;207(1):30-38.

35. Badan Pusat Statistik. Timor Tengah Selatan dalam Angka. Soe: BPS Kabupaten Timor Tengah Selatan; 2016. 